MILENA GAMMAITONI ${ }^{1}$

\title{
THE SOCIAL BEHAVIOUR OF THE POET DURING THE NEW FREEDOM OF GLOBALISATION: THE CASE OF WISŁAWA SZYMBORSKA IN ITALY AND POLAND
}

\begin{abstract}
This article tries to answer to some questions the author finds of vital importance to stimulate a deeper reflection on the meaning and on the real background of our lives today, starting with the role of literature and poetry and the way they are analysed by sociology. The discourse is focused on the role of science and a particular Polish poet, Wisława Szymborska and the reception of her works in Italy and Poland. All this is presented in the frame of tradition, globalisation and broadly understood freedom.
\end{abstract}

Key words: sociology, literature, poetry, reading

I chose to study the poet Wisława Szymborska as her work had already reached Italy before she received the Nobel Prize (1996), thanks to a translation by Pietro Marchesani. Thus, by 1995 she had already obtained astonishing success both among critics and readers, despite the small circulation and distribution of her work. Before winning the Nobel Prize, Wisława Szymborska had become popular in Sweden with her books being bestsellers, while after the prize, her work was translated into different languages in the United States. In Italy, Marchesani's translation for Adelphi sold out, with her books having the highest sales in the poetry sector in Italy. Indeed, her work has been translated into 36 languages, while web sites (articles, essays, blogs, music videos inspired by her texts, fan groups on Facebook) have quintupled in the span of a few years. Moreover, the first

\footnotetext{
${ }^{1}$ Prof.; Roma Tre University; e-mail: milena.gammaitoni@uniroma3.it.
} 
volume published in Italy after Szymborska's winning of the Nobel Prize, which combines different collections of her poems, namely View with Grain of Sand (Adelphi), has progressed from 13,000 copies sold from 1998 to 2004 to 35,000 today, while sales for The Joy of Writing have reached 80,000 copies. Generally, books of poems sell between 1,000 and 3,000 copies in Italy.

The poetess's death in February 2012, has left a documentary (Szymborska, 2013) that she enjoyed traveling around Europe: a testament of freedom, lightness, being always ready to smile at oneself and at the world.

In this time of globalisation I would like to intervene by posing a question that is also one of the points of my book (Gammaitoni, 2005), namely: what is the role of literature today, how has it changed and how does a local writer, a Polish one in this case, become global and free of ideology or politics? Here, "global" means that readers from different nationalities with different individual and social life stories far from the Polish experience identify themselves with Szymborska.

Today, Norberto Bobbio emphasises the crisis produced starting from the failure of the organic intellectual, becoming a paralysis of intellectual thinking. Some sociologists fluctuate between harshly critical visions, as those of Franco Ferrarotti on the transformation and disappearance of the intellectual as a free-thinker, becoming in today's cultural industry, and world of cybernetics, a professional, a provider of opera, or on interpretations that are based on the history of rationality, as those of Alberto Izzo who believed in the possibilities of posing the best arguments.

The story and works of Wisława Szymborska well represent the crisis of the organic intellectual, a devotee of Sartre, lived through and experiencing the transformation of the intelligentsia of ex-communist Eastern Countries. Her first collection of poems was published in 1953, This Is What We Live For, and is characterised by a strong propagandist intent of communist ideology. However, following the first scandals resulting from large-scales political purges, the poetess did not renew her subscription to the party and wrote poems that are completely different in style and content. From working as an intellectual professional for a literary magazine, after her defection from the party she was demoted to being a literary columnist and writing reviews of books of every type, from botany to literature. She also slowly withdrew from the Association of Writers while her public role became increasingly blurred, with sparks of participation regarding some collective issues. 
However, we must not forget the lesson of Hannah Arendt regarding private acts as actions which are never singular but plural. Although one may not appear publicly as she herself often did, one affects the community and becomes part of it by writing, as every work, including works of art, remains in the world, separates from the individual living an independent life: their act remains public and perpetuated thanks to the memory of their audience.

I had all the elements to believe that the story of the life of Szymborska could depict the passing of an intellectual convinced of committing themselves to the implementation of a utopia and that, disappointed by the violence produced on man, a delicate phase of revision of the old world was employed for a utopia become a partial ideology (Mannheim, 1929) and, perhaps, the next step in the search for a life of a different fate for humanity. Szymborska's disenchantment and confusion is alive and makes poetry the pragma of internal dissension. With the end of communism, her works came slowly along the path towards the global market.

In the early nineties, laws on copyright were passed in Poland, with dissident authors and publishing houses departing from publishing and copying works in a clandestine manner. Although there was finally the breath of freedom in the process of democratisation and modernisation of the country, the author as an intellectual seemed to die off, deconsecrated (Barthes, 1953). A new world opened up in which artists and intellectuals had to redefine both themselves and the world itself. This is the crucial juncture in which they seem to be more committed to redefining themselves individually, than redefining the world or proposing a different idea on how to live in this new world. Being does not correspond with appearance, in the silence of the appearance of the artist-intellectual's works is to act and find the shape of appearance: private space is the prelude to the space of the public and for the public. In spite of everything, a public act is reborn in the private act of the writer, the work of art being born as a reworking of a collective consciousness (Goldmann, 1977).

My analysis considers two nationalities: Italian and Polish. I address questions regarding Polish intellectuals (considering them as privileged observers, focused interviews with university professors, lecturers, journalists, writers), among them Czesław Miłosz, and various Italians. I delivered 1,000 questionnaires (avalanche sampling) to students (from Krakow, Warsaw, Rome, Genoa). 
I therefore believe that outlining the answers to some of the questions I addressed to intellectuals will help one to understand the issue at hand.

Szymborska is immediately recognised as all of the participants have read her poems while at secondary school.

The best-remembered poem is that which may be found in the anthology books of secondary schools. It is a poem that traces a line between the poet's affiliation to the Communist Party and her moving away from communist ideology. The title of the collection Appeal to the Yeti is often confused with the title of a poem contained in the collection Notes from a Nonexistent Himalayan Expedition.

For Szymborska's scholars, her most important collection is People on the Bridge.

They do not identify Szymborska with communism, and generally justify her behaviour as an act of trust far from the logic of power logistics and from easy political opportunism. Szymborska as a poet, according to the people interviewed, emerged with the collection People on the Bridge.

Her most appreciated poems by the Poles have been translated into Italian.

Regarding the question whether Szymborska represents the Polish literary tradition, the majority answered that although she represents it, at the same time she brings new styles and themes rarely used by Polish poets, namely: freedom of thought, irony (the absence of nationalism, victimisation and martyrdom), conciseness, hermetism; with philosophical, existentialist and minimalist themes. The Polish tradition is represented by the use of a collective subject, proverbs, songs and references to Polish characters and situations.

One of the first questions I asked Polish scholars concerned the role of the poet in Poland, was how and whether it has changed compared to the past. They answered unanimously that the poet of the last twenty years is not the voice of people, the leading guide to freedom from foreign oppression anymore. Although during the communist period poetry was propagandist, linked to the regime's ideology, there was also a group of underground poets writing against the authorities. Today, all these things are useless and the poet finds their inspiration in themselves and in everyday life. They reflect the sense of crisis and confusion of ordinary people, and do not lead souls as they are a soul among other souls. Therefore, each interviewed person by citing different quotations and by choosing different poems, finds in Szymborska's poetics the same questions whose 
answers cannot be found by anyone, namely: death; the meaning of life; the horrors of war; the impossibility to describe pain; risk; but even the positive aspects of being oblivious that helps one to be renewed and start again from the beginning; historic events and their meaning in the life of an individual; the ability to enjoy the marginal moments of everyday life and recognise in such moments the paradox of the randomness and/or superfluousness of such events.

Szymborska never speaks with the typical emphasis belonging to a poet's or philosopher's wisdom. She led a simple life (in the opinion of those interviewed) and, even in this case, did not want to be distinguished by ordinary people. In her poems she asks philosophical questions whose answers she does not know, does not want to find or is unable to do so. Her questions reassure the reader when they have to face the finite nature of humanity or the impossibility of finding ultimate resolutions.

Moreover, none of them consider her works as a typically female way of writing, or as feminist. Her themes are universal, even if some poems provide evidence of a special kind of observation that some interviewees find belonging to the life of women. These include, for instance, poems such as: The Onion, Ruben's women, Lot's wife. In any case, this is considered to be a marginal aspect.

From the second half of the $19^{\text {th }}$ century the role of the poet and poetess in Italy and Poland had a different history and a different development: in Italy we had poets dealing more with intimist themes than with nationalistic ones, while during the early twentieth century, artistic vanguards and futurists linked themselves to politics and power, but then deviated looking for different ways. Regarding women in Italy, who obtained the right to vote in 1947, poetesses are autobiographical writers torn between feminist claims (civil and political rights), or they are conservative in their ideas and/or describe the social reality they have to live in. In Poland, the role of the poet was that of a martyr for their nation, or that of a knight, of the uhlan fighting for their homeland and for religious principles, fighting to obtain a social identity, as well as for justice. Women seem to have a weaker voice, and while in the last twenty years we can find openly feminist writers, in their works autobiography prevails, meaning it is an intimist way of writing.

Even in Miłosz's opinion, Szymborska, whom he had chosen as the best contemporary female writer in his History of Polish literature, emerged because "her discipline made her able to practice philosophical poetry with 
an incisiveness equal only to Herbert's" (Miłosz, 1984, p. 183). Therefore, does Szymborska "globalise" the conflicted feelings of contemporary man? I think she does.

However, as many other artists, Szymborska knew what clearly sustained W. H. Auden, namely that each and every act of poetry is a political act, that the publication of a piece of writing is an assumption of responsibility for what one says, as it denies and doubts.

In 1986, the poetess published the poem Children of Our Age where she well describes how every act, although with no original political intention becomes, as a consequence, a public and political act. In it we find Hannah Arendt's meaning of a public act:

\section{Children of Our Age}

We are children of our age, it's a political age.

All day long, all through the night, all affairs--yours, ours, theirs-are political affairs.

Whether you like it or not, your genes have a political past, your skin, a political cast, your eyes, a political slant.

Whatever you say reverberates, whatever you don't say speaks for itself. So either way you're talking politics.

Even when you take to the woods, you're taking political steps on political grounds.

Apolitical poems are also political, and above us shines a moon no longer purely lunar.

To be or not to be, that is the question. And though it troubles the digestion it's a question, as always, of politics. 
To acquire a political meaning you don't even have to be human. Raw material will do, or protein feed, or crude oil,

or a conference table whose shape was quarreled over for months; Should we arbitrate life and death at a round table or a square one?

Meanwhile, people perished, animals died, houses burned, and the fields ran wild just as in times immemorial and less political.

Nor is she exempt from describing the horrors of the Holocaust:

Write it. Write. In ordinary ink / on ordinary paper: they were given no food / they all died of hunger. 'All. How many? / It's a big meadow. How much grass / for each one?' Write: I don't know. / History counts its skeletons in round numbers. / A thousand and one remains a thousand, / as though the one had never existed: / an imaginary embryo, an empty cradle / an ABC never read, / ... Write: how silent. Yes. (Hunger Camp at Jasło).

History unfolds mainly around grisly facts; I do not agree with the idea that after some event, as terrible it is no longer possible to write. For the simple fact that in that event it follows another equally terrible, then yet another ... (Szymborska's Nobel Prize speech).

Szymborska passes from the description of the hero (heroes are companion communists), the protagonist of the story in which the narrator is US for the social construction of a collective identity, alternating with one's writing that interrogates oneself, a Polish actor (of a country that has become democratic), foreign readers (Poland opened up to the international market in 1990), history, fate, in which nothing is certain regarding definitions and therefore opens up a new freedom to speak publicly, especially when the political vicissitudes are so strong that the poet could not remain silent and take refuge in the private sphere: the concept of unpredictable, unconscious, free evil emerges. Szymborska uses the lesson of Hannah 
Arendt regarding the "banality of evil"; an example being the poem Hitler's First Photograph:

And who's this little fellow in his itty-bitty robe? / That's tiny baby Adolf, the Hitlers little boy! / Will he grow up to be an LL.D.? Or a tenor in Vienna's Opera House? / . . . Where will those tootsy-wootsies finally wander? / . . No one hears howling dogs, or fate's footsteps. / A history teacher loosens his collar / and yawns over homework.

Man as an individual, in the meaning of being an exception with respect to the world, can, according to Szymborska, learn from the mistakes of history and not cause suffering to others, while the general problems which bind us are the development of a shared awareness by human society.

It is thus that the poetess outlines an epistemology of the poetics existing in the world, conducting a social act aware of past and present, in which the ethics of the poet is manifested, the responsibility to show a respectful method of reflection which readers may grasp, thanks to which each reader will perhaps find space for their answers and actions. As no man is free not to choose, the nonexistence of absolute freedom (not awareness, not the responsibility of one's actions) emerges clearly in her poems.

For this reason there is no truth, but many existential truths, aware and responsible choices (action and non-action is always a choice: as in Hamlet's: "To die, to sleep, - to sleep - perchance to dream . .."). Many existential truths which are never moralistic, but descriptive and which clarify, without placing proscriptions (apart from the Decalogue) on what is hatred, what is violence, what are the consequences, how much pain is to be suffered, supports Umberto Eco's view that:

Every artistic form may well be seen, if not as a substitute for scientific knowledge, as an epistemological metaphor: that is to say that in every century, the way in which the forms of art are structured reflects this - in the form of similarity, precisely, resolution of the subject in figure - the way in which science or in any case the culture of the age saw the reality (Eco, 2003, p. 43). ${ }^{2}$

There is a strong emphasis on the ethics of the poet, the function of which should be the pursuit of happiness. In Literary Letters, Szymborska criticises precisely the absence of ethics to one of the many aspiring writers:

\footnotetext{
${ }^{2}$ All translations come from Kay Mc Carthy unless indicated otherwise.
} 
that dying father who has ordered surgeons to transfer his brilliant brain into the head of his son, arouses fear, apart from the fact that the son was consenting or less. A brain in which a similar idea was born is not suitable - in our opinion - to make future mankind happy (ibid.).

At the same time Szymborska throws many crucial "hows" and many "whys" into her verses. She wants the freedom of an actor to discover and define them, certainly a freedom educated towards a method of reflection that one may define as global and oriented to the globalisation of culture in dialogue with other arts. ${ }^{3}$

\section{THE ROLE OF THE POET IN AN AGE OF GLOBALISATION, THE ANSWERS OF POETS AND OF SOCIOLOGY}

The works of Wisława Szymborska, as has been demonstrated, do not provide definitive answers and often do not formulate them at all. She offers a path of knowledge, an epistemology of the poetic act, in front of which sociological analysis enters into crisis. It is a crisis shared by intellectuals and artists, who in the first person, faced with the great questions of life, respond with the statement "I don't know." As the poet and director Sepulveda writes, to say something is to exist, and it seems Szymborska maintains a dialogue going through the crux of the matter: "Do not hold it against me, $\mathrm{O}$ speech, that I borrow weighty words and then labour to make them light" (Szymborska, 1999, p. 19). Why does the poet have the task of making what is not light seem lighter? This is because the use of language has to invite the reader in, not to turn them away from universal themes, such as the meaning of life, death, violence, gratuitous evil, pain, happiness, solitude and boredom.

${ }^{3}$ For example the poem Love At First Sight was used in the film Turn Left, Turn Right, starring Takeshi Kaneshiro and Gigi Leung. Three Colors: Red, a film directed by Krzysztof Kieślowski, was inspired by Szymborska's poem, Love At First Sight. Szymborska's poem Nothing Twice was turned into a song by composer Andrzej Munkowski performed by Lucja Prus in 1965 making her poetry known in Poland, rock singer Kora's cover of Nothing Twice was a hit in 1994. In her final years, Szymborska collaborated with Polish jazz trumpeter Tomasz Stańko who dedicated his record Wisława (2013) to her memory taking inspiration for the compositions from their collaboration and her poetry. 
Mario Luzi, a living Italian poet, writes that the first thing that a poet has to do is to help one forget, and forget themselves too, the fact of being an actor. They will be close to the truth when in their work the actors become others, nature in its fragmentary circumstances, as well as in its deep principles, and they appear both as the interpreter and the witness.

The sensitivity of modern poetry is transposed and identified with linguistic activity. There is no linguistic engineering or technique able to offer the poet real invention if it does not communicate or irradiate a single emotion. Where this is absent we lack the premises to consider poetry as an undebatable reality in the reality of the world.

The period in which we are living is one a characterised by a triumphal scientism where "how" prevails over "when" and "why", thereby banishing poetry to some kind of prehistoric ghetto; if we give ourselves the chance to look at its surface, it dedicates to poetry the same detailed attention it would pay to an object, or better, a product. I am saying this with a social and economic meaning. This transforms books of poetry into a reason for publishing houses to ensure their closing balances are in the red. If this makes the issuing of poetry useless, then the role of the poet becomes itself useless as they will be read by the few, with those few people not contributing to enlarging the cash flows of the publishing market. A sociologist of literature from Warsaw, Stanisław Siekierski denounces the same problems indicated by the Italian sociologist, Franco Ferrarotti (1998), underlining this paradox thus: "Everyone becomes a writer but nobody can read." Therefore, the number of published books increases while the number of readers diminishes.

How should one interpret these statistics and, most of all, interpret the various artistic phenomena? Husserl opened the twentieth century with his "crisis of the western conscience and the transcendental phenomenology" (Ferrarotti, 1998, p. 53), with positivist scientism reducing reality to an empirically observable enumeration of a series of facts and phenomena. Without the help of observable events the scientist cannot define his theories, laws, conceptual categories: he cannot define and explain the reality of things, of collective actions. He renounces Durkheim for sociology to inquire into the psyche, soul, spirit and metaphysics. This is what the philosophers did not dare to do. Let us not forget that philosophers until the second half of the twentieth century were mathematicians and physicists, thus educated men in the so-called hard disciplines. While trying to solve the debates opened by German historicism, with Dilthey and 
Windelband science has actually entered a crisis and together with it the scientist's role, as well as the poet's role, albeit at a different moment; that is what Max Weber (1997) defined as disenchantment of the world and that which Karl Manheim drew up as the intellectual's invincible perplexity torn between ideology and utopia.

Sociology tends to abandon the field of things not observable through facts. The spirit, the soul, the emotions, the internal movements that generate actions and the interpretation of the actions themselves, remain fields that cannot be explored, areas reserved for literature and philosophy. We can statistically study the fruition of the arts. "How" and technique, as I have just stated, prevail over "when" and, most of all, "why", which is the reason why quantitative methods are preferred to qualitative ones. We must not forget that a Polish sociologist, Zaniecki was the founder of a new analysis method based on autobiography.

Let us now take a look at how some sociologists study the arts. From Max Weber, Mannheim, Elias in Germany, Lukács in Hungary, Mills in the United States, Ferrarotti and Serravezza in Italy. Max Weber looks at art eliminating aesthetic judgement: the sociologist's purpose is to understand why a certain artistic technique stood out and developed at a specific historical moment, without considering its beauty. Lukács (1964) describes socialist realism (literature representing reality the way a mirror would), at the same time it being able to demystify reified forms of the social scheme. Mannheim finds three levels of analysis, namely: objective (the work in its aesthetic meaning); expressive (the artist's life); documentary (the work records the culture where it was produced). Mills, in the sociological imagination, writes that the sociologist's job itself is an art: the art of intuition, of a global and synthetic vision, he/she is a craftsman of society, "the main political and intellectual task of a sociologist is to define the elements of discomfort and indifference typical of contemporary man. It is the main commitment imposed to him by other mind workers, from the physician to the artists" (Lukács, 1964, p. 187). The analysis develops on three main dimensions, namely: the structure of society as a whole; what is the place of a certain society in the pattern of human history; and what kind of men and women prevail in this society at this moment.

Elias, Ferrarotti and Serravezza base their sociological analyses on the meeting point between individual history and social history and on retrieving the intellectual's guiding role, as well as that of the artist, all convinced that each symbolic expression represents a specific social organisation. 
Ferrarotti criticises particularly the technical perfection that becomes a perfection of a mere nothing. Homo sentiens is man himself. He never stops repeating the Greek language term téchne, meaning art, the way of proceeding. Thus, this signifies means, not purpose, not the "eternal return to the identical", but rather imagination and creation: "From here artist and artisan, talking about those who are able to solve a specific question, satisfy one's need, but even invent it" (Ferrarotti, 1991, p. 38). In his mind, today it is the Homo sentiens that prevails, writing in "Books, readers, society" that he is neither self conscious, conscious of others, nor of the society he lives in. Their memory, memories, their capacity to select, rather than the project, the utopia of the becoming, meaning and curiosity for the mystery of chance, for destiny, seems to have vanished, the edges escaping, along with scents and flavours.

The position we mean to assume is to conceive a creative action by referring it to society, to the historical moment when it comes to life. Art is not the result of an a priori action integrated into society, its reflection, but is rather essentially critical, demystifying and propulsory. In the history of art we can find periods and historical-social contests that gave birth to artistic creations that we could define as didactic if compared to the social system; and extremely critical, in contrast. In the west, during the preindustrial period, art, intended as an element of social cohesion is what prevails, while during the industrial period, art still strongly assumes imitative features. A typical example is the case of socialist realism, where censorship prevented the exhibition of original, innovative and demystifying artistic works. Moreover, production and mass consumption impose industrial rhythms on those artists willing to enter the market.

Therefore, we cannot place artistic activity apart from other human activities, nor consider it as a marginal, unreal, solitary inspiration of the individual facing the reality of the world; a dialectical relationship exists between the individual artist and the artistic community, together with the different ways through which time makes itself real. We have to consider that "even if the individual refuses sometimes to communicate and jealous of his own individuality, he enters a solitary and hidden praxis, and goes under the illusion of being himself alone with his soul, instead the social element is still part of him expressing itself through the language he uses. This language is not a private business, but it has an intersubjective essence, and involves various individuals" (Adorno, 1972, p. 59). 
Although the artist, in the mind of the author, has often lived and anticipated contemporary forms of living, in some European nations in the $19^{\text {th }}$ century - for instance their departure from Court - will lead them to an unstable economic condition, a chronic state of unemployment, that is very well described in Norbert Elias' Sociology of a Genius, W.A. Mozart. The artist can denounce and reveal the ambiguity of existence through his life and creations, swinging between rational and irrational actions, Pareto's residual, unconscious production, the effect of the contemplative moment, the fantastic, pleasant, imaginary, illusionary, passionate, contradictory, that is not included in the categories of the rational action, which are instrumental, made to be efficient, as well as somewhat utilitarian and economical. The fact that statistics do not consider the category of artist in surveying reports and censuses, as it is considered as non-remunerative, makes this even clearer. If we look for them within the data, we may suppose they are hidden among the entrepreneurs, professionals, housewives or the unemployed.

At the ceremony at which she was awarded the Nobel Prize for literature in 1996, the poetess Szymborska affirms:

there are no poetry professors. If it were like that, that would mean we would be dealing with a profession ... some kind of a certificate with a stamp on. On such an assumption the Russian poet, who then received the Nobel Prize, Joseph Brodsky, was condemned to political confinement. He was considered a parasite.

Although contemplative action, typical of the artist, is not included within the analyses of the contemporary way of acting, that is no good reason to forget its existence, that they are the origin and the life experience that give birth to the text books which we all study since our early years at school.

The sociology of art, and its literary branch, have started a discussion on the relationship between science and art, on the admissibility of the scientific study of art and of the social representativeness of an individual person that gives the soul motion, observes and describes what they see and feel about human existence. Thomas Khun underlines how these two different disciplines, art and science, are, instead, following two similar development patterns, namely: the creative innovation, common to both of them, leads to their dealing with subjects such as the role of schools, 
traditions, mutable standard values and transformed intuitive methods. Art is torn from science because of disputes taking place within science itself: the world of values and that of facts, the subjective and objective, intuition and deduction. However, "the more accurately we try to distinguish the artist from the scientist, the harder becomes our task" (Khun, 1972, p. 10), and we create a false problem, an aporia itself. What these two disciplines have in common is their estranged existence from the audience, a typical reaction of contemporaneity, a feature of both science and art. That science and art are both productions of the human behaviour is a truism, not without any consequence for this reason. The problems of style for science regarding art and theory may be, in Kuhn's opinion, the price we pay because we ignore the obvious. We have to investigate the intention on the basis of the communicative action of the artist; for this reason, it would be interesting to discover why they have privileged the refinement of one form over that of another.

Stylistic choice is the means to express the reason of the artist, while besides the use of style we also find the story of a personal and collective life. Every matter of style, says Lukács, is a sociological problem that must be investigated on what kind of interdependency exists between the social conditioning and the genesis of literary contents, even understanding the ways through which literature influences social reality. Not being scared to be regarded as non-scientific, Lukács recognises the poet as possessing the capacity, whose roots are mysterious in themselves (the experimental and scientific knowledge facing them is powerless), to represent the social reality in its typicality. When he talks about typicality he means the convergence towards a representation "of all the important aspects characterising the dynamic unity where real literature represents life, every important social, moral, psychological contradiction of an age" (Lukács, 1972, p. 103).

The poet's wisdom consists of their being able to recognise in each single deviation of reality what is typical and individual in order that we may presume that both art and literature represent, by making it apparent, the undulatory action that survives and even changes. For this reason, the sociologist is interested when a mainly technical transformation meet some contents made up of feelings in that aesthetic judgement will not be a judgement on the aesthetic value, but will be rather the observation of a change for which they will have to understand its rational and substantive purpose. 
Both Lukács and Hanna Arendt mention Heine as an example. He conceived poetry as a means of struggle, some of his verses revealing the way the poetic form denounces and escapes censure: "it blows, bawls, thunders everyday / until the last oppressor will escape. / It sings only in this direction / but keep your poem / the more you can, close to vagueness" (Heine, 1917, p. 65). As Maria Zambrano writes:

the mask, is an instrument to participate, it becomes a contemplation object a posteriori, we use it to obtain something, a means to get in touch with a kind of reality that we are allowed to touch only by imitating it, an imitation that becomes a transformation. Consequently, it is a way to enter reality, some specific realities (Zambrano, 2001, p. 37).

Arendt, who walked the road of exile against the conquest of power by a totalitarian regime, writes in the distance: in the prologue of Antigone's Grave the philosopher uses a strange word, that we can hardly translate: destrierro - tra ('exile') and tierra ('land').

Hannah Arendt gets her inspiration from Weber's dichotomy pariah/ parvenu, as well as Hebrew writers and poets who defended their identity from assimilation, from their becoming parvenus. While translating a Kafka's tale $\operatorname{Er}$ ('Him'), Arendt uses rhetoric to distinguish who a person is from what a person is: what we can tell others about us as a single individual cannot be seen aprioristically in its pure essence by the subject, who, being a person related to what we are and to the way other people describe, knows and recognises themselves within the common singularity. It often happens that in an eastern European country's literature "me" becomes "us", masculine and feminine become one, communist ideology and postcommunism transform the intimist description into a collective way of feeling, ex-ante and ex-post. The encouraging and consolatory hero becomes an anti-hero/anti-heroine fighting absolutist political systems. The hero, as a protagonist and/or as a co-protagonist, a speaking voice, becomes "us".

Miłosz's thoughts on the book, My Europe, were thus, to "oblige him to unveil at least a piece of that soaring knowledge hard to convey to the west, that he had stored up: a book made up not only of personal memories, but also of those that were geopolitical: the powerful ghost of certain lands within the Grand Duchy of Lithuania, when this was a bigger power than that of Russia" (Miłosz, 1996, p. 71). Miłosz writes about "a seized Europe, where the habit is to erase history, time, names, but where 
civilization's intrigues were such as to make every single man you met different from the other, not because of his own specific peculiarity, but rather as a representative of a group, of a class or of a people" (ibid., p. 72).

Thus, can a disguising poem, a metaphor of the metaphors, answer a questioning sociologist? Are creativity and life stories sociologically representative? The Russian poetess Anna Achmatova in 1957 wrote:

During the terrible years of Yezhovism I spent seventeen years queuing in front of the Leningrad prisons. Once someone "recognised me". So a woman with livid lips, who stood right behind me, and that, for sure, had never heard my name, shook from the typical torpor that characterised us and asked me in my ear (everyone used to whisper over there):

- But, can you describe that?

And I said:

- I can.

Then some kind of a smile slipped on what had been her face once (Cerasuolo Pertusi, 1974, p. 37).

This is how, Alfredo de Paz writes, the idea of a trans-individual subject able to go beyond the psychoanalytical theories on artistic production was born. From this emerges the primary need for coherence and totality that marks out social and human life. For this reason, the literary act cannot be considered as an abstract act, as it is based on the main relationships between people themselves. The language the artist uses is mainly the tradition and legacy of experience of using a certain kind of language following forms, genres, styles. At the same time, as Goldmann affirms, they receive simultaneously a whole series of mental categories, values and ways of imparting values that we can define with the general term of world vision. Although it is impossible for the individual to escape such circumstances, this is where they get their inspiration without being completely aware. In the imaginary universe expressed inside a work, the purpose of genetic structuralism is to find the structures of a world vision belonging to the social group which the writer is linked to in someway, and that which he took them from, representing or declaring a collective consciousness.

Franco Ferrarotti defines scientific truth itself as an intersubjective truth, to be verified empirically, as science itself is nothing but the verification of a personal idea, of an arbitrary action, as Goldmann writes, a continuous adventure between tradition and innovation that joins it to an artistic production. 
In the present day, contemporary art increasingly arouses sentiment, emotion and curiosity; it is strictly individual and solitary, an unshared fruition, typical of the glo-local process. An artistic production, and any culture it may come from, is consumed at home (home video and Internet). The social use of art works is no longer communal nor an expression of coexistence, of common social opportunities, of institutional pathways and of psycho-social consequences. Therefore, aporia has come to the fore in post-modern society as far as the production/reception of an artistic work is concerned: while artists attempt, as their centuries-long artisticsocial function supposes, to speak to a public, the technological society has changed the ontology of the recipient: the public has dissolved, it no longer exists. We live in an era of the individual consumer, who often buys without consuming: that is, they buy a work of art to distinguish themselves and to conform, at the same time, to the social class they belong to (Bourdieu, 1979).

In different historical periods, in different social contexts, and at turning-points of artistic development as in the case of the "artistic avantgarde", artists have taken on what we define today as the "role of the intellectual". They were "guides" in proprio (futurists, surrealists, postmodernists), precisely because they had not yet been inserted within the structures of commercial production.

Even though the artist has entered the control room of market/publishing production only with the avant-garde, they have held a central role in society since antiquity. In the past they had had religious, moral, political and educational functions; the origin of their talent was considered as divine (magical in other cultures), and, once desacralised, it was defined as mysterious. Art was synonymous with wisdom and science in the humanistic concept of the classics.

The use and functions have now changed, while art in general has passed from a principally religious and/or celebrative function (to thrive as long as European Courts would thrive), to a greatly individualistic artistic creation within which the artist, no longer the Court-employed professional, attempts to reconcile their expressive liberty with the preferences of the public at large. The fields of art have progressively become subdivided into sectors: literature has become the field of those who write anything from prose to poetry; the musician becomes the composer and/or performer; the educator is a figure in itself. 
As the social conditions of art change, the modes of its fruition change also. For example, pictures were once private, literature passed from either being read out loud or sung as was done in the classical world, being read in a murmured way as in the medieval cloisters, being read out loud in public places to finally arrive at the reading in one's mind typical of the modern world. Unfortunately, art was something only men could aspire to. In fact, the role of women was not contemplated. Unless they chose the religious life, young women were rarely taught to read and write. They could not exhibit themselves in public places (in Church or outside of the Court, apart from the rarest exceptions). If a woman succeeded in writing secretly, she could not sign her work until the later part of the $19^{\text {th }}$ century. Indeed, this is the subject of a book I plan to have published about the life story of female artists (musicians, artists, philosophers) from the Middle Ages to today.

Regarding the state of art, it is precisely the "irrational" - an aspect which still today has not been very much explored by sociology - which has given life to several forms of mythical tales, full of symbols and allegories. Within this space emerges the relationship between the idea and the real, as studied by Edgar Morin:

We constantly need the assistance of the real, but what is effectively the real if not an idea that designates it as such? The real is not imperative, as it is believed. Its appearances are fragile and its essence is hidden or unknown. Its substance, its origin, its foundations, its becoming, is uncertain. Its complexity is interwoven with uncertainties. Hence its extreme weakness before the formidable super-reality of the myth, religion, ideology and even an idea (2005, p. 22; italics as originally in Morin's book).

Furthermore, the history of Western thought has rarely stopped placing its confidence in the form of rational thought being seen as the only road towards progress. Rationality is hence seen as the point of reference of human progress.

In attempting to set aside the inevitability of rationality, and thus of rationalism, we can begin to question the presupposition of their infallibility if we follow a certain epistemological debate that progressively accepts a state of incompleteness and probabilism towards which all the so-called "hard" sciences are moving. "In this regard it must be specified," Franco Ferrarotti writes, "that the hypothetic-probabilist conception of science 
implies instead a presumption of a conventionalist nature, which denies all possible residues of 'objectivism'"' (1998, p. 33). If it participates in scientific knowledge, the form of irrational thought necessarily participates in all human knowledge, reflecting itself in behaviour. A "science" called upon to understand human phenomena, as in the case of sociology in regards to social actions, is obliged to realise just that.

Historically, it may also happen that a malade imaginaire of a group, or of a society, takes control: one only has to think about Nazi or communist regimes. This occurs when, as Gilbert Durand explains (2010), an absence of pedagogy of the imagination is registered: at that point, the malade imaginaire generates "totalitarian myths". From the viewpoint of social research, it is good to consider the genetics of the imagination because, on a theoretical level, nothing is good or bad in an absolute sense: only upon passing into action we do enter into the ethical dimension that connotes myths as values. Therefore, it is the praxis that connotes the mythological value of a world vision (telling one of/about the world).

It is in this sense that the sociology of art was able to enrich itself with an approach that is attentive to the social action of artists, deeply connected with the social imagination of which they are both the voice and the mirror. Therefore: the subjective imagination of the artist + social imagination $\rightarrow$ artistic-social behaviour as fusion of the rational and "irrational".

The definition of the "artist", in sociology, for example, is often employed to exemplify the concept of "deviance". Authors, such as Robert Merton, Lewis Coser, Talcott Parsons, Daniel Bell and other contemporary sociologists, consider the artist either as a rebel or as an innovator who frequently tends to distance themselves from the rules. Once the role and the function of the artist are clearly established, can they still be defined as a "moral guide", and "intellectual"?

Actually, still today the literary author is a socially marginal figure. Those who live on personal earnings derived from selling copies of their own works are rare. Moreover, these are the only ones who gain visibility: they are listened to when they speak about society, either through their works or when they are interviewed. However, the great majority of authors practice their literary work in the same way it has been practiced for centuries: as their second job. Their products are almost invisible and their voice does not pervade the media and appears unheard.

In the 1960s, the Italian writer Luigi Malerba noted that the economic boom society, engrossed in its technological race and interest in products 
of practical use, was not yet ready to accept the commerce of intellectual work. On the contrary, literary work, continues Malerba, was still viewed as an extraneous body that does not produce wealth: it was neither an automobile, nor a plastic bucket, nor a new packet of cigarettes: why should society occupy itself with a new "unknown" book, printed in ten thousand copies, when they could reprint the classics? Although the writer had suddenly won their own independence in line with the "law" - their literary conscience - a sector of the market that would welcome their products still did not exist. Thus, they were forced to live a "ghost-career". Even though some got to experience popularity, economic independence was unattainable: they could almost never succeed in liberating themselves from their second jobs or from the chain of editing imposed by the publishers.

Hence, the social and psychological discomfort that plagues the author, unresolved up to today, will be investigated: intellectual and manual activities are still two separate sectors. The post-modern artist is no longer an artisan bound to the Renaissance apparatus (that lasted until the end of the $19^{\text {th }}$ century). However, they still do not succeed in producing and distributing their works independently. Society still considers them as "unnecessary". At its best, it sees them as a positive "parasite", or a good "producer" of mass-produced works of art when they are supplying products for mass consumption (TV shows, commercial works empty of aesthetic and social research, and so on). They have lost their physiognomy as a creator. Caudwell called this uncomfortable role "the false position of the poet as a producer for the market" (Caudwell, 1996, p. 63).

As Martha Nussbaum writes in Artistic Justice, artists are one of the first and constant agents of both socialisation - think of childhood fairy tales - and of ethical and emphatic understanding of the different psychic and social realities of humanity. Every form of artistic behaviour (their private life, public declarations, produced works), by the nature of its human creation, expresses a thought, a socially conditioned and conditioning vision of the world. Artists are the "interpreters" of the world.

Alfred Schutz, Peter Berger and Ralph Dahrendorf unabashedly confess their debt to art, whose help they seek when unable to give explanations through science. Sociology describes the "whys" of the world, while art explains the "hows": "How must feel a man after winning a kingdom but losing his soul?" Only artistic stages strengthen the idea of social behaviour in which everything is interconnected, where every behaviour, 
Pirandello-like, puts other behaviours into action and is, at the same time, influenced by the same behaviour it produces.

In the past, sociologists used artistic examples to demonstrate certain collective social and mental processes; the earliest approaches included the analysis of life stories which were incorporated into research as ancillary, but never central illustrative material.

In sociology today, we are increasingly more aware that the construction of reality takes place as well through artistic experiences, from fairy tales to school books; from music to design; from extemporaneous installations and readings to reading festivals (for example: Biennale di Venezia, some festivals in Mantua, Rome, the Tremiti Islands, London, and so on).

The theory of modern and contemporary Western artistic behaviour would not have a foundation if it were a monological theory. The behaviour of the artist is always dialogical: today they are looking even more for dialogue, exactly when the traditional market is cutting them out of institutional dialogue. The artist, especially he or she who is young and independent, lives on "discourse" with others, in a dialogical dimension.

I intend to learn about the new roles, behaviours and values of contemporary artists, their imaginary forms of cultural syncretism transmitted into their works, at times using playfulness (Roland Barthes), as well as transforming consumption into a new "religion of the masses" (Edgar Morin) which makes a substitute satisfaction of an artistic object (Arnold Hauser), for all the malaise of social and private lives. Moreover, of course, not all works of art are harbingers of positive content, but may also herald and justify forms of negativity and social violence.

The field of studies concerning the sociology of the arts arose at the very beginning of the $20^{\text {th }}$ century in the works of the German thinkers, Georg Simmel and Max Weber. Consequently, it developed with a strong statistical connotation within the School of Bordeaux in France, under Robert Escarpit. Thereafter, it developed a socio-structural association with Pierre Bourdieu. In the United States, Howard Becker and Vera Zolberg worked contemporaneously on artistic phenomena with a sociological perspective of symbolic interactionalism. Today, in France we have a longer Bourdieu tradition and new viewpoints such as Peter Menger, who analyses artistic markets, and Nathalie Heinich, who analyses the question of identity and relations with public institutions. Thus, the above-presented project arises from a need to study this subject in depth and, with an interdisciplinary and international research group, develop research in this field. 
Regarding the theory on social action in art, we have neither a strong nor a long tradition: in the USA Howard Becker has analysed the artist's social action through symbolic internationalism while Wendy Grinswold has conducted a structuralist analysis of such action; in Italy Franco Crespi founded the sociology of culture and analysed social action within sociological theories. In UK and Germany we have the Weberian tradition (Alfred and Max Weber).

Although it is possible to investigate statistically the fruition of works of arts, the problem of technique and how to study them remains. By mixing different methods, namely qualitative and quantitative, I have tried to define the social action of the poet, along with Szymborska's poems, during a period a new kind of freedom where various aspects of culture are undergoing a process of globalisation.

\section{BIBLIOGRAPHY}

Adorno, W. T. (1972). Sociology of music. Torino: Einaudi.

Barthes, R. (1953). Le Degré zéro de l'écriture. Paris: Éditions du Seuil.

Becker, H. (2008). I mondi dell'arte. Bologna: II Mulino.

Bikont, A., Szczęsna, J. (1997). Pamiq̨tkowe rupiecie, przyjaciele i sny Wisławy Szymborskiej [Cianfrusaglie memorabili. Amici e sogni di Wisława Szymborska]. Warszawa: Prószyński i S-ka.

Bourdieu, P. (1979). La distinction. Bologna: II Mulino.

Caudwell, L. (1996). Poetic Justice. In C. Greblo (Ed.), Giustizia poetica. Immaginazione letteraria e vita civile. Milano: Mimesis.

Cerasuolo Pertusi, M. R. (1974). Anna Achmatova nella poesia russa del '900. Trieste: C.E.D.D.

Clementi, F. (2008). Alla ricerca dell'uomo in Wislawa Szymborska. Milano: Adelphi.

De Paz, A. (1980). Sociologia e critica delle arti. Bologna: CLUEB.

Dewey, J. (1995). Arte come esperienza e altri scritti. Firenze: La Nuova Italia Editrice.

Durand, G. (2010). La sortie du xxe siècle. Introduction à la mythodologie, Figures mythiques et visages de l'ouvre, L'Âme tigrée, Un comte sous l'acacia. (Réédition des quatre ouvrages). Paris: CNRS Éditions.

Eco, U. (2003). Dire quasi la stessa cosa. Esperienze di traduzione. Milano: Bompiani.

Escarpit, R. (1970). Le littéraire et le social. Parigi: Harmattan.

Ferrarotti, F. (1991). Homo sentiens. Napoli: Liguori.

Ferrarotti, F. (1998). Libri, lettori, società. Napoli: Liguori.

Gammaitoni, M. (2005). L'agire sociale del poeta. Wislawa Szymborska nella vita dei lettori in Polonia e in Italia. Milano: Franco Angeli.

Gammaitoni, M. (2015). Le arti e la politica, le risposte della sociologia. Padova: Claup.

Goldmann, L. (1977). Le structuralisme génétique. Paris: Denoel-Gonthier. 
Heine, H. (1917). Poems of Heinrich Heine. Three hundred and Twenty-five Poems (L. Untermeyer, Trans.). New York: Henry Holt.

Heinich, N. (2009). Sociologia dell'arte. Parigi: Harmattan.

Khun, T. (1972). The Theory of Scientific Revolution. Torino: Einaudi.

Lodoli, M. (2013, July 13). "La gioia di scrivere" della poetessa Wislawa Szymborska scala la classifica delle vendite. La Repubblica.

Lorenc, H. (1997). Omaggio a Wisława Szymborska. Firenze: Ministero per i Beni Culturali e Ambientali, Biblioteca Nazionale Centrale di Firenze (edizione fuori commercio).

Lukács, G. (1964). Scritti di sociologia della letteratura. Milano: Mondadori.

Lukács, G. (1972). Sociology of novel. Roma: Editori Riuniti.

Mannheim, K. (1929). Ideologia e Utopia. Bologna: II Mulino.

Miłosz, Cz. (1984). The history of Polish literature. Berkeley: University of California Press.

Miłosz, Cz. (1985). La mia Europa. Milano: Adelphi.

Miłosz, Cz. (1996). My Europe. New Haven: Yale University Press.

Morin, E. (2005). L'uomo e la morte. Roma: Meltemi.

Nussbaum, M. C. (1996). I/ giudizio del poeta: immaginazione letteraria e vita civile. Milano: Feltrinelli.

Origlia, G. (1979). L’abisso esorcizzato. Wislawa Szymborska. Nuova Rivista Europea. 9, 22-31.

Sartre, J. P. (1960). Che cos'è la letteratura? Milano: Feltrinelli.

Szymborska, W. (1999). Vista con granello di sabbia. Milano: Adelphi.

Szymborska, W. (2009). La gioia di scrivere. Tutte le poesie (1945-2009). Milano: Adelphi.

Szymborska, W. (2013). La vita a volte è sopportabile. Ritratto ironico di Wisława Szymborska. Bellinzona: Casagrande.

Weber, M. (1997). Il metodo nelle scienze storico sociali. Torino: Einaudi.

Wolff, J. (1983). Sociologia delle arti. Bologna: II Mulino.

Zagajewski, A. (1982). Polonia: uno stato all'ombra dell'Unione Sovietica. Casale Monferrato: Marietti.

Zambrano, M. (2001). Per un sapere dell'anima. Milano: Raffaello Cortina Editore.

Zolberg, V. (1994). Sociologia dell'arte. Bologna: II Mulino. 